N.A. Shestopal, O.P. Linnik, N.P. Smirnova

\title{
INFLUENCE OF METAL AND NON-METAL IONS DOPING ON THE STRUCTURAL AND PHOTOCATALYTIC PROPERTIES OF TITANIA FILMS
}

\author{
Chuiko Institute of Surface Chemistry of National Academy of Sciences of Ukraine \\ 17 General Naumov Str., Kyiv, 03164, Ukraine, E-mail: nat-shestopal@yandex.ua
}

The metal $\left(\mathrm{Zn}^{2+}\right.$ or $\left.\mathrm{Zr}^{4+}\right)$ and non-metal (nitrogen) doped titania films are synthesized by sol-gel method. High absorption in the visible region is observed and the band gap values are estimated for indirect electron transition. The decrease in the intensity and broadening of the anatase peaks in XRD spectra for $\mathrm{TiO}_{2} / \mathrm{N}$ films with increasing urea contents are observed. Anatase formation in the films with double doping agents is proven by Raman measurements. XPS clarified the chemical state of the elements, their surface ratios and the incorporation of nitrogen in the matrix of the synthesized films. XPS results show that the substitutional nitrogen is only registered for $\mathrm{TiO}_{2} / \mathrm{Zr}{ }^{4+} / \mathrm{N}$. Photocatalytic properties are estimated in the process of tetracycline destruction reaction. The increase of the film activity by factor three is noted for $\mathrm{TiO}_{2} / \mathrm{N}$. Modification $\mathrm{TiO}_{2} / \mathrm{N}$ by metal ions has no influence on the photocatalytic properties under UV and visible light.

Keywords: metal and non-metal doped titania, optical properties, XRD, Raman measurements, XPS, photocatalytic activity

\section{INTRODUCTION}

The activity of $\mathrm{TiO}_{2}$ under solar irradiation is negligible and the modification of the semiconductors by various metal and non-metal ions is required to broad its absorption in near ultraviolet and visible light. Non-metal doping of $\mathrm{TiO}_{2}$ has shown the great potential in visible light active photocatalysis with nitrogen being the most promising dopant. Nitrogen can be introduced in the $\mathrm{TiO}_{2}$ structure due to its comparable atomic size with oxygen, small ionization energy and high stability. Doping of $\mathrm{TiO}_{2}$ by non-metals is based on: a) band gap narrowing proposed by Asashi et $a l$. [1]; b) impurity energy levels formation above the valence band as a result of the substitution of oxygen atom by nitrogen in titania stated by Irie $e t$ al. [2]; c) formation of oxygen vacancies concluded by Ihara et al. [3]. It is reported that $\mathrm{TiO}_{2}$ doped with substitutional nitrogen has shallow acceptor states above the valence state while doping with interstitial nitrogen leads to isolated impurity states in the middle of the band gap where energy levels of the impurity are mainly hybridized by $\mathrm{N} 2 p$ states and $\mathrm{O} 2 p$ states. [4]. The nature of the nitrogen species is under discussion in numerous scientific publications. Various
$\mathrm{N}$-containing species incorporated in oxide matrix were proposed [5-8]. However, it is supposed that nitrogen causes the formation of oxygen vacancies and color centers that are responsible for the visible-light activity $[9,10]$. It is reported that $\mathrm{N}$-doping leads to band-gap narrowing by an anodically shifted valence band edge [11] or nitrogen-centered energy levels located just above the valence band edge [12-14]. The nature of the nitrogen species formed from mixing titania powder and urea with the following treating at $400{ }^{\circ} \mathrm{C}$ and their chemical and physical properties were investigated by group of Prof. Kisch in detail $[8,15,16]$. The obtained findings indicated that a poly(triamino-s-triazine) sensitizer chemically bounded to the semiconductor is formed after calcination of 1:2 (wt/wt) mixture of titania and urea at $400{ }^{\circ} \mathrm{C}$ in a rotating flask. The mechanism of this reaction is discussed: i) heating urea at $300-420^{\circ} \mathrm{C}$ produces ammonia and isocyanic acid; ii) isocyanic acid in the presence of titania surface $\mathrm{OH}$ groups is catalytically converted into melamine in the same temperature range by cyclotrimerization of cyanamide; iii) condensation to a mixture of polytriazine amines (formation of melem and melon); iv) condensation between the $s$-triazine amino and $\mathrm{OH}$ groups of titania generates 
Ti-N bonds. Thus, the visible light absorbing triazine derivative becomes chemically bound to the semiconductor. Accordingly, the modification is not successful when titania is dehydroxylated before use by heating it in vacuo at $400{ }^{\circ} \mathrm{C}$. It is concluded that the visible-light photocatalytic activity of urea modified titania does not originate from the presence of nitridic, amidic, and nitrogen oxide species or color centers but does from melamine condensation products acting as visiblelight sensitizers [17]. The formation of $\mathrm{Ti}_{1-\mathrm{x}} \mathrm{Zr}_{\mathrm{x}} \mathrm{O}_{2}$ was achieved by zirconium incorporation into $\mathrm{TiO}_{2}$ lattice by sol-gel method. It is demonstrated that the formation of $\mathrm{Zr}-\mathrm{O}-\mathrm{Ti}$ bonds has an influence on the thermal stability during sintering of the mesoporous structure of the films, surface texture and optical properties as well as in the changes of number of surface active sites for nanocomposite films [18]. In our previous paper, the co-doped with nitrogen $\mathrm{TiO}_{2} / \mathrm{ZrO}_{2}$ films were obtained by Pulsed Laser Deposition method under different synthesis conditions [19]. The films obtained in nitrogen atmosphere or its mixtures with methane are characterized by the formation of $\mathrm{O}-\mathrm{Ti}-\mathrm{N}$ bonds in the oxide matrix as shown by XPS analysis. The binary oxide materials such as $\mathrm{TiO}_{2} / \mathrm{ZnO}$ are reported to demonstrate the improved catalytic and photocatalytic performances due to the increased adsorption and effective separation of photogenerated electronhole pairs [20, 21].

Therefore, we pointed out on the investigation of the electronic, optical and photocatalytic properties of doubly doped (metal and non-metal ions) $\mathrm{TiO}_{2}$ films to clarify their mutual influence on the photocatalytic properties of the semiconductor.

\section{EXPERIMENTAL PART}

Mesoporous $\mathrm{TiO}_{2}$ thin films were synthesized by the sol-gel method using titanium tetraisopropoxide as a titania source and a threeblock copolymer of polyethyleneoxide and polypropyleneoxide $\quad(\mathrm{PEO})_{20}(\mathrm{PPO})_{70}(\mathrm{PEO})_{20}$ (Pluronic P123) as a template in alcoholic medium. Concentrated $\mathrm{HClO}_{4}$ and acetylacetone were added to the precursor as stabilizers. The molar ratio of the components in the sol for films deposition was as following: $\mathrm{Ti}(\mathrm{O} i-\mathrm{Pr})_{4}: \mathrm{P} 123$ : acetylacetone : $\mathrm{H}_{2} \mathrm{O}: \mathrm{C}_{2} \mathrm{H}_{5} \mathrm{OH}: \mathrm{HClO}_{4}=1: 0.05: 0.5: 1: 40: 1$. A solution of urea $\left(\mathrm{CO}\left(\mathrm{NH}_{2}\right)_{2}\right)$ with 1 or 5 or $10 \mathrm{~mol} . \%$ and zinc acetate $\left(\mathrm{Zn}\left(\mathrm{OOCCH}_{3}\right)_{2}\right)$ or zirconium propoxide $\left(\mathrm{Zr}\left(\mathrm{OCH}_{2} \mathrm{CH}_{2} \mathrm{CH}_{3}\right)_{4}\right)$ with $5 \mathrm{~mol} . \%$ were added under vigorous stirring. The one-layered films were deposited by dip-coating procedure at a withdrawal rate $1.5 \mathrm{~mm} / \mathrm{s}$. The films were left for $1 \mathrm{~h}$ for hydrolysis and heated in air at $450{ }^{\circ} \mathrm{C}$ for $1 \mathrm{~h}$ with the heating rate of $3{ }^{\circ} \mathrm{C} / \mathrm{min}$. Photocatalytic activity of the films was assessed via tetracycline hydrochloride (TC) degradation. The film was immersed in $40 \mathrm{ml}$ of an aqueous solution of $2 \times 10^{-5} \mathrm{~mol} / \mathrm{L}$ TC. The reaction temperature was kept constant $\left(20^{\circ} \mathrm{C}\right)$ during the experimental procedure. The change of $\mathrm{TC}$ concentration was monitored with a Lambda 35 UV-vis spectrophotometer (PerkinElmer) every $20 \mathrm{~min}$ at $\lambda=357 \mathrm{~nm}$. The film was immersed in the solution until complete adsorption in the dark occurred and then irradiated by a $1000 \mathrm{~W}$ middlepressure mercury lamp for $90 \mathrm{~min}$. The distance lamp-reactor was set at $90 \mathrm{~cm}$. A blank experiment was carried out where a bare glass was used instead of film. No significant changes in the absorption spectra of the liquid were observed for the blank. For testing the visible light sensitivity, a filter transmitting light with $\lambda>380 \mathrm{~nm}$ was introduced into the photocatalytic setup.

\section{RESULTS AND DISCUSSION}

Absorption spectra and band gap energy values of the mesoporous films are presented in Fig. 1. Among titania film doped with different amount of urea $(1,5$, and $10 \mathrm{~mol} . \%)$, the $\mathrm{TiO}_{2} / \mathrm{N}(5 \%)$ film showed the highest absorption intensity in the visible region and significant shift of absorption edge to the longer wavelengths (Table 1).

As 1 and $10 \%$ urea doped $\mathrm{TiO}_{2}$ films exhibit no absorption in visible light as well as the photocatalytic activity is significantly lower than that of $\mathrm{TiO}_{2} / \mathrm{N}(5 \%$ ) (see below), all further investigation have been performed with the samples doped with $5 \%$ urea. The films of $\mathrm{TiO}_{2}$ and $\mathrm{TiO}_{2} / \mathrm{M}^{\mathrm{n}+}$ doped with $5 \%$ urea are characterized by high absorption in the range of $350-550 \mathrm{~nm}$. It must be noted that the highest intensity in the visible range is observed for the $\mathrm{TiO}_{2} / \mathrm{Zn}^{2+} / \mathrm{N}$ (Fig. 1, curve 4). It is suggested that the formation of complexes between zinc ions and urea during gel ripening occurs [22] leading to the retention of nitrogen containing species in the oxide lattice over heating. The band gap values $\left(E_{\mathrm{g}}\right)$ of the samples (Table 1) were estimated for indirect electron transition from the dependence of $(\alpha h v)^{1 / 2} \sim f(h v)$ and extrapolation of the linear plot of experimental curve to $(\alpha)^{1 / 2}=0$. Widening of band gap for some samples in comparison with pure $\mathrm{TiO}_{2}$ can be caused by the decrease in the 
crystalline particle size, i.e. the quantum-size effect [23]. The band gap of urea doped films (except $\left.\mathrm{TiO}_{2} / \mathrm{Zr}^{4+} / \mathrm{N}\right)$ is narrowed suggesting the formation of sublevels above the valence band as a result of oxygen substitution by nitrogen.

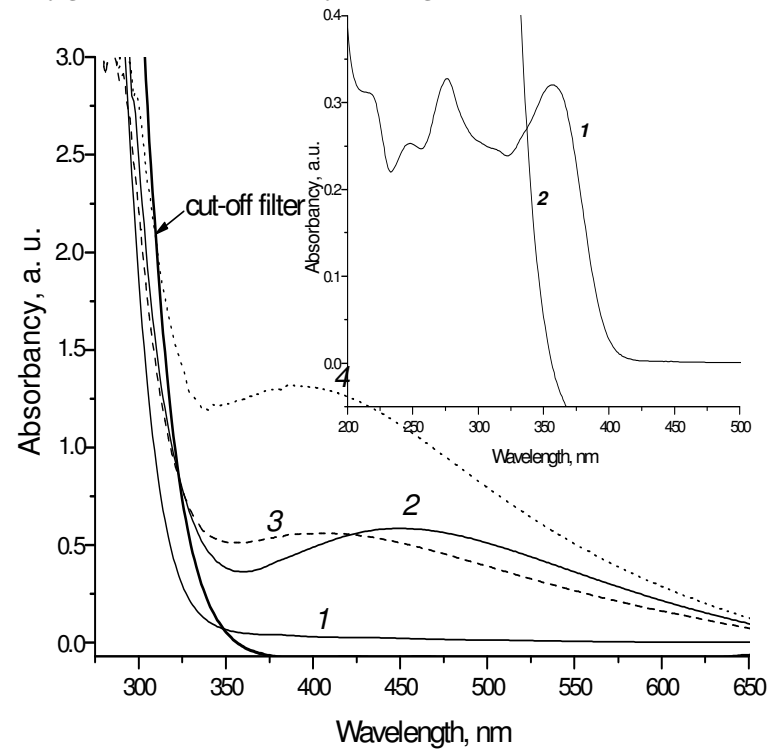

Fig. 1. Absorption spectra of $\mathrm{TiO}_{2}(1), \mathrm{TiO}_{2} / \mathrm{N}$ (2), $\mathrm{TiO}_{2} / \mathrm{Zr}^{4+} / \mathrm{N}(3), \mathrm{TiO}_{2} / \mathrm{Zn}^{2+} / \mathrm{N}(4)$ and the cut- off filter with $\lambda \geq 340 \mathrm{~nm}$ (bold line). Insert: absorption spectra of TC (1) and the cut- off filter with $\lambda \geq 340 \mathrm{~nm}$ (2)

Table 1. The band gap energy values of $\mathrm{TiO}_{2}$ doped films for indirect transition

\begin{tabular}{lc}
\hline \multicolumn{1}{c}{ Film } & $\boldsymbol{E}_{\mathbf{g}}, \mathbf{e V}$ \\
\hline $\mathrm{TiO}_{2}$ & 3.6 \\
$\mathrm{TiO}_{2} / \mathrm{N}(1 \%)$ & 3.8 \\
$\mathrm{TiO}_{2} / \mathrm{N}(5 \%)$ & 3.3 \\
$\mathrm{TiO}_{2} / \mathrm{N}(10 \%)$ & 3.9 \\
$\mathrm{TiO}_{2} / \mathrm{Zr}^{4+}$ & 3.7 \\
$\mathrm{TiO}_{2} / \mathrm{Zr}^{4+} / \mathrm{N}(5 \%)$ & 3.7 \\
$\mathrm{TiO}_{2} / \mathrm{Zn}^{2+}$ & 3.8 \\
$\mathrm{TiO}_{2} / \mathrm{Zn}^{2+} / \mathrm{N}(5 \%)$ & 3.5 \\
\hline
\end{tabular}

XRD measurements (not shown here) revealed that anatase in $\mathrm{TiO}_{2} / \mathrm{N}$ films $(1,5$ end $10 \%)$ was formed. However, the intensity of the XRD peaks and their broadening with increasing urea content is observed due to the deceleration of $\mathrm{TiO}_{2}$ crystallization. As a result, the formation of numerous titania crystallization centers onto $\mathrm{TiO}_{2} / \mathrm{N}$ occurs where the aggregation and growth of nanoparticles don't take place. It is known that the presence of nitrogen-containing species (up to
$10 \%)$ in $\mathrm{TiO}_{2}$ structure lowers the crystalization to anatase [24, 25]

As a proof of anatase formation in nitrogencontaining films, the Raman spectra of $\mathrm{TiO}_{2} / \mathrm{N}$ and $\mathrm{TiO}_{2} / \mathrm{Zn}^{2+} / \mathrm{N}$ are presented in Fig. 2. The high intensive Raman peaks at 145, 398, 518 and $640 \mathrm{~cm}^{-1}$ (Fig. 2 curve $a$ ) are observed for $\mathrm{TiO}_{2} / \mathrm{N}$ films. These peaks are related to the formation of photocatalytically active anatase phase. The intensity of these lines is drastically decreased for the sample contained zinc ions (Fig. 2 curve $b$ ). It could be caused by the formation of much lower particle size of titania in $\mathrm{TiO}_{2} / \mathrm{Zn}^{2+} / \mathrm{N}$ in comparison with $\mathrm{TiO}_{2} / \mathrm{N}$. Since no lines belonged to zinc oxide is registered, it is concluded about effective incorporation of $\mathrm{Zn}^{2+}$ ions into semiconductive matrix.

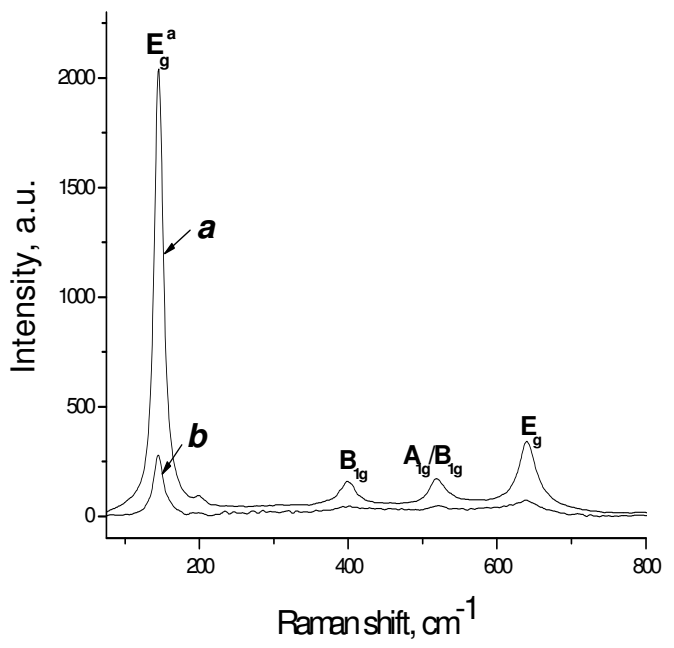

Fig. 2. Raman spectra of $\mathrm{TiO}_{2} / \mathrm{N}(a)$ and $\mathrm{TiO}_{2} / \mathrm{Zn}^{2+} / \mathrm{N}$ (b) treated at $450{ }^{\circ} \mathrm{C}$

XPS is used to clarify the chemical state of elements, their surface ratio and the key point is whether the nitrogen is incorporated into the oxide matrix and its state. The XPS analysis of Ti, N, O and $\mathrm{C}$ atomic levels and their intensity are presented in the Table 2.

There is no definite opinion about the XPS measurements of N1s binding energy where the values of $396-397 \mathrm{eV}$ assigned to the $\mathrm{N}-\mathrm{Ti}-\mathrm{N}$ [26, 27] or $\mathrm{O}-\mathrm{Ti}-\mathrm{N}$ bonds [7] are reported. The formation of $\mathrm{N}-\mathrm{N}$ or $\mathrm{N}-\mathrm{C}$ or $\mathrm{N}-\mathrm{O}$ groups or chemisorbed dinitrogen is suggested at higher energies of 400-403 eV [7, 8, 28-30]. Nitrogen $1 s$ binding energies of 399.2 and $400.5 \mathrm{eV}$ are measured for a mixture of solid urea and $\mathrm{TiO}_{2}$ powder calcined at $400{ }^{\circ} \mathrm{C}$ corresponded to carbon nitrides $\quad(399-400 \mathrm{eV}, \quad \mathrm{C}=\mathrm{N}-\mathrm{C})$ and similar 
graphite-like phases $\left(400.6 \mathrm{eV}, \mathrm{N}-\mathrm{C}_{\mathrm{sp} 2}\right)$, and of polycyanogen $\left(399.0,400.5 \mathrm{eV}(-\mathrm{C}=\mathrm{N}-)_{\mathrm{x}}\right)$ [15]. The authors reported the production of poly(triamino-s-triazine) derivatives covalently attached to the semiconductor after thermal treatment.

Since urea is used as the doping agent and the calcination temperature is the same for our films and the samples reported herein [31], the N1s peak of $\mathrm{TiO}_{2} / \mathrm{N}$ films at $400.6 \mathrm{eV}$ could be related to the $\mathrm{N}-\mathrm{C}$ species in $\mathrm{TiO}_{2}$ matrix. However, the additional investigation of urea conversion in the metal alkoxide sol used for the film preparation is required. It must be noted that the values of the binding energy of N1s peak are lowered for $\mathrm{TiO}_{2} / \mathrm{M}^{\mathrm{n}+} / \mathrm{N}$ films. The appearance of $\mathrm{N} 1 s$ peak with $\mathrm{E}_{\mathrm{B}}=400.0 \mathrm{eV}$ for $\mathrm{TiO}_{2} / \mathrm{Zn}^{2+} / \mathrm{N}$ is also attributed to the formation of $\mathrm{N}-\mathrm{C}$ species in $\mathrm{TiO}_{2}$ matrix. An increase in the relative intensities of $\mathrm{N} 1 s$ peak for $\mathrm{TiO}_{2} / \mathrm{Zn}^{2+} / \mathrm{N}$ in 2.5 times in comparison with $\mathrm{TiO}_{2} / \mathrm{N}$ shows the effect of zinc ions on the building up of such species on the oxide surface.

Table 2. Binding energy values and their relative intensities of Ti, N, O and C elements

\begin{tabular}{lcccccc}
\hline \multicolumn{1}{c}{ Element } & \multicolumn{2}{c}{$\mathbf{T i O}_{2} / \mathbf{N}$} & \multicolumn{2}{c}{$\mathbf{T i O}_{2} / \mathbf{Z n}^{2+} / \mathbf{N}$} & \multicolumn{2}{c}{$\mathbf{T i O}_{2} / \mathbf{Z r}^{\mathbf{4 +}} / \mathbf{N}$} \\
& $\boldsymbol{E}_{\mathbf{B}}, \mathbf{e V}$ & $\boldsymbol{I}, \boldsymbol{\%}$ & $\boldsymbol{E}_{\mathbf{B}}, \mathbf{e V}$ & $\mathbf{I} \boldsymbol{\%}$ & $\boldsymbol{E}_{\mathbf{B}}, \mathbf{e V}$ & $\mathbf{I , \%}$ \\
\hline $\mathrm{Ti} 2 p_{3 / 2}$ & 459.4 & 4.7 & 459.0 & 4.4 & 459.2 & 3.5 \\
$\mathrm{~N} 1 s$ & 400.6 & 0.6 & 400.0 & 1.6 & 396.0 & 0.4 \\
$\mathrm{O} 1 s$ & 530.9 & 20.5 & 530.5 & 23.3 & 530.7 & 23.8 \\
$\mathrm{C} 1 s$ & 283.9 & 73.1 & 283.2 & 70.1 & 283.7 & 71.8 \\
$\mathrm{Zn} 2 p_{3 / 2}$ & - & - & 1024.2 & 0.6 & - & - \\
$\mathrm{Zr} 3 d_{5 / 2}$ & - & - & - & - & 182.7 & 0.5 \\
\hline
\end{tabular}

XPS results of $\mathrm{TiO}_{2} / \mathrm{Zn}^{2+}$ films revealed the presence of separated $\mathrm{ZnO}$ phase with $E_{\mathrm{B}}=1021.7 \mathrm{eV}$ corresponding $\mathrm{O}-\mathrm{Zn}-\mathrm{O}$ bonds (not shown here). The shift of $\mathrm{Zn} 2 p_{3 / 2}$ line maximum to $1024.2 \mathrm{eV}$ in $\mathrm{TiO}_{2} / \mathrm{Zn}^{2+} / \mathrm{N}$ is caused by the formation of Ti-O-Zn bonds [31]. The similar observation was reported for $\mathrm{TiO}_{2} / \mathrm{Zn}^{2+}$ and goldcontaining $\mathrm{TiO}_{2} / \mathrm{Zn}^{2+}$ films suggesting the complexes formation between tetrachloroauric ions and zinc ions during sol ripening [32]. We predict that urea could also form the complexes with zinc(II) acetate in the sol leading to Ti-O-Zn bonds formation. The relative intensities of $\mathrm{N} 1 s$ peak for $\mathrm{TiO}_{2} / \mathrm{Zn}^{2+} / \mathrm{N}$ is higher in 2.5 times in comparison with $\mathrm{TiO}_{2} / \mathrm{N}$ and suggest keeping of not only zinc ions but also $\mathrm{N}$-species onto oxide surface. For $\mathrm{TiO}_{2} / \mathrm{Zr}^{4+} / \mathrm{N}$ film the nitrogen in the form of substitutional atom $(\mathrm{O}-\mathrm{Ti}-\mathrm{N})$ is incorporated in to $\mathrm{TiO}_{2}$ matrix as the binding energy of $\mathrm{N} 1 s$ electrons is situated at $396.0 \mathrm{eV}$ $[33,34]$. Hence, the oxygen substitution by nitrogen is more efficient in zirconium containing films.

Line of Ti2 $p_{3 / 2}$ of all samples contains a single peak in the range of 459.2-459.4 eV and confirms the presence of $\mathrm{TiO}_{2}[35,36]$. The XPS peak in the range of $530-531 \mathrm{eV}$ for all samples corresponds to $\mathrm{O}^{2-}$ ions of crystalline oxide matrix. The presence of $\mathrm{C}-\mathrm{C}$ (elemental carbon) bonds is confirmed by $E_{\mathrm{B}}=283.9 \mathrm{eV}$ [37].

To test the photocatalytic activity of $\mathrm{TiO}_{2} / \mathrm{N}$ and $\mathrm{TiO}_{2} / \mathrm{Me}^{\mathrm{n}+} / \mathrm{N}$, tetracycline hydrochloride (TC) is chosen as the antibiotic recognized as a new type of pollutants. The uncontrolled use of antibiotics in farm industry and medicine leads to their building up in the water sources and soil. Its accumulation results in the bacteria resistance and consecutive mutagenation in the living organisms [38].

Table 3. The percentage of adsorbed and destructed TC $(\lambda=357 \mathrm{~nm})$ over the $\mathrm{TiO}_{2} / \mathrm{N}, \mathrm{TiO}_{2} / \mathrm{M}^{\mathrm{n}+}$ and $\mathrm{TiO}_{2} / \mathrm{Me}^{\mathrm{n}+} / \mathrm{N}$ films after $90 \mathrm{~min} \mathrm{UV}$ or visible irradiation

\begin{tabular}{lccc}
\hline \multicolumn{1}{c}{ Film } & UV, \% & Vis., \% & Ads., \% \\
\hline Blank (glass) & 6 & 2 & 0.6 \\
$\mathrm{TiO}_{2}$ & 11 & 5 & 2.0 \\
$\mathrm{TiO}_{2} / \mathrm{N}(1 \%)$ & 26 & 9 & 4.0 \\
$\mathrm{TiO}_{2} / \mathrm{N}(5 \%)$ & 30 & 16 & 2.4 \\
$\mathrm{TiO}_{2} / \mathrm{N}(10 \%)$ & 16 & 9 & 5.1 \\
$\mathrm{TiO}_{2} / \mathrm{Zr}^{4+}$ & 29 & 11 & 8.4 \\
$\mathrm{TiO}_{2} / \mathrm{Zr}^{4+} / \mathrm{N}$ & 26 & 10 & 1.6 \\
$\mathrm{TiO}_{2} / \mathrm{Zn}^{2+}$ & 25 & 11 & 6.2 \\
$\mathrm{TiO}_{2} / \mathrm{Zn}^{2+} / \mathrm{N}$ & 25 & 13 & 2.8 \\
\hline
\end{tabular}

The photocatalytic activity of $\mathrm{TiO}_{2} / \mathrm{N}$ films is increased in comparison with pure $\mathrm{TiO}_{2}$ film under both UV and visible light (Table 3). The highest activity is observed for the film with $5 \%$ of urea 
(in three times higher than $\mathrm{TiO}_{2}$ ). The increase in photocatalytic activity under UV light for $\mathrm{TiO}_{2} / \mathrm{Zn}^{2+}$ and $\mathrm{TiO}_{2} / \mathrm{Zr}^{4+}$ films is explained by higher surface acidity comparing with $\mathrm{TiO}_{2}$ film and the appropriate positions of the conduction and valence bands ( $\mathrm{CB}$ and $\mathrm{VB}$ ) of the semiconductor [23, 39].

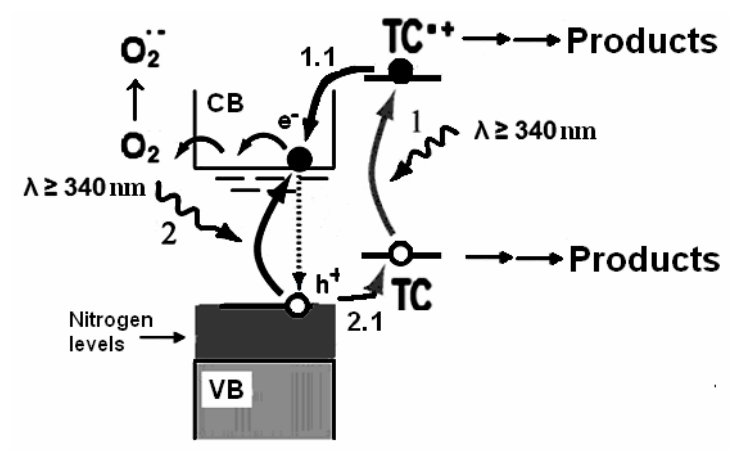

Fig. 3. Possible routes of photocatalytic processes of TC destruction over $\mathrm{TiO}_{2} / \mathrm{N}$ and $\mathrm{TiO}_{2} / \mathrm{Me}^{\mathrm{n}+} / \mathrm{N}$ films under visible light irradiation

Photocatalytic activity of the films under visible light is studied using a cut-off filter with $\lambda \geq 340 \mathrm{~nm}$ (Fig. 1). It is obvious that the absorption edge of semiconductor is cut and the photocatalytic process can only occur through the excitation of an electron from the additional $\mathrm{N}$-sublevels formed in the valence band of $\mathrm{TiO}_{2}$. However, the cut-off filter does not prevent the excitation of TC molecule (Fig. 1, insert) that is why the TC degradation can follow via the two different ways such as i) the photoexcitation of TC molecule, i.e. indirect photocatalysis (Fig. 3, route 1) and ii) the excitation of the electron from the $\mathrm{N}$-sublevels in VB to CB (Fig. 3, route 2). It is clear that the pure $\mathrm{TiO}_{2}$ film is inactive under visible light showing the low probability for both photocatalytic pathways. Since the nitrogen doping does not change the $\mathrm{CB}$ and $\mathrm{VB}$ positions of semiconductor, the formation of additional energetic N-sublevels could be proposed [40]. Therefore, the route 2 is more feasible for $\mathrm{TiO}_{2} / \mathrm{N}$ films: the electron is transferred to the $\mathrm{CB}$ and the photoformed hole reacts with the TC molecule (steps 2.1). In the case of $\mathrm{TiO}_{2} / \mathrm{M}^{\mathrm{n}+}$ films the higher activity (2 times in comparing with $\mathrm{TiO}_{2}$ ) under visible light can be caused by the change of the $\mathrm{CB}$ and the VB due to the metal ions doping $[23,39]$ leading to the better adsorption of TC molecules onto the surface and more easier electron transfer from the excited TC molecule (route 1.1). No difference in the photocatalytic activity is noted for $\mathrm{TiO}_{2} / \mathrm{M}^{\mathrm{nt}} / \mathrm{N}$ under visible light comparing with $\mathrm{TiO}_{2} / \mathrm{M}^{\mathrm{nt}}$ films. It is supposed that the route 1 is only possible for doubly doped samples due to the low probability of the electron excitation from the N-sublevels. It is possible due to the formation of the structure defects by double doping that makes easier the recombination process.

Hence, the chemical state of nitrogen in $\mathrm{TiO}_{2} / \mathrm{M}^{\mathrm{nt}} / \mathrm{N}$ films is strongly dependent on the type of the metal ions as shown by XPS measurements. In addition, this study showed that doping of $\mathrm{TiO}_{2} / \mathrm{N}$ by zinc ions brings to the keeping of nitrogen ions onto the film surface due to the complex formation on the stage of the gel formation. The crystallization rate of titania is lowered by doping higher content of urea as well as by metal ions signed by XRD and Raman investigations. Nitrogen-containing $\mathrm{TiO}_{2}$ exhibits the activity enhance in photocatalytic destruction of TC under both UV and visible light. Doping $\mathrm{TiO}_{2} / \mathrm{N}$ by metals changes the route of photocatalytic process. 


\title{
Вплив допування йонами металу та неметалу на структурні і фотокаталітичні властивості плівок діоксиду титану
}

\author{
Н.О. Шестопаль, О.П. Ліннік, Н.П. Смірнова \\ Інститут хімії поверхні ім. О.О. Чуйка Начіональної академії наук Украӥни \\ вул. Генерала Наумова, 17, Київ, 03164, Україна, nat-shestopal@yandex.иа
}

\begin{abstract}
Золь-гель методом синтезовані плівки діоксиду титану, допованого йонами металу $\left(\mathrm{Zn}^{2+}\right.$ або $\left.\mathrm{Zr}^{4+}\right)$ та неметалу (азот). Спостерігається значне поглинання плівки в видимій області та оцінено значення ширини забороненої зони для непрямих електронних переходів. Результати рентгенофазового аналізу свідчать про утворення кристалічної фази анатазу, однак спостерігається зниження інтенсивності та уширення його піку зі збільшенням вмісту сечовини. Методом комбінаиійного розсіювання також показано, що відбувається формування анатазу в плівках з подвійним допантом. Хімічний стан елементів, їх співвідношення на поверхні та впровадження азоту в кристалічну матрищю досліджено за допомогою рентгенофотоелектронної спектроскопії. Отримані результати показали, що азот замімує атоми кисню тільки в структурі $\mathrm{TiO}_{2} / \mathrm{Zr}^{4+} / \mathrm{N}$. Досліджено фотокаталітичні властивості в процесі розкладання тетрацикліну гідрохлориду. Збільшення активності в три рази спостерігалось для плівки $\mathrm{TiO}_{2} / \mathrm{N}$. Модифікація йонами металів не вплинула на фотокаталітичні властивості під ультрафіолетовим та видимим світлом.
\end{abstract}

Ключові слова: допований йонами металу та неметалу діоксид титану, оптичні властивості, РФА, метод кобінаційного розсіювання, РФЕС, фотокаталітична активність

\section{Влияние допирования ионами металла и неметалла на структурные и фотокаталитические свойства пленок диоксида титана}

\section{Н.А. Шестопаль, О.П. Линник, Н.П. Смирнова}

Институт химии поверхности им. А.А. Чуйко Национальной академии наук Украины ул. Генерала Наумова, 17, Киев, 03164, Украина, nat-shestopal@yandex.иа

Золь-гель методом синтезированы пленки диоксида титана, допированного ионами металла $\left(\mathrm{Zn}^{2+}\right.$ или $\mathrm{Zr}^{4+}$ ) и неметалла (азот). Наблюдается значительное поглощение пленки в видимой области и оценено значение ширины запрещенной зоны для непрямых электронных переходов. Результаты рентгенофазового анализа свидетельствуют об образовании кристаллической фазы анатаза, однако наблюдается понижение интенсивности и уширение его пика с увеличением содержания мочевины. Методом комбинационного рассеяния показано также, что происходит формирование анатаза в пленках с двойным допантом. Химическое состояние элементов, их соотношение на поверхности и внедрение азота в кристаллическую матрииу исследовано с помощью рентгенофотоэлектронной спектроскопии. Полученные результаты показали, что азот замещает атомы кислорода только в структуре $\mathrm{TiO}_{2} / \mathrm{Zr}^{4+} / \mathrm{N}$. Исследованы фотокаталитические свойства в проиессе разложения тетрациклина гидрохорида. Увеличение активности в три раза наблюдалось для пленки $\mathrm{TiO}_{2} / \mathrm{N}$. Модификаиия ионами металлов не влияла на фотокаталитические свойства под ультрафиолетовылм и видимым светом.

Ключевые слова: допированый ионами метала и неметала диоксид титана, оптические свойства, РФА, метод комбинационного рассеяния, РФЭС, фотокаталитическая активность 


\section{REFERENCES}

1. Asahi R., Morikawa T., Ohwaki T. et al. Visible-light photocatalysis in nitrogen-doped titanium dioxide, Science, 293 (2001) 269.

2. Irie H., Watanabe Y., Hashimoto K. Nitrogenconcentration dependence on photocatalytic activity of $\mathrm{TiO}_{2-\mathrm{x}} \mathrm{N}_{\mathrm{x}}$ powders, J. Phys. Chem. B, (2003) 5483.

3. Ihara T., Miyoshi M., Triyama Y. et al. Visiblelight-active titanium oxide photocatalyst realized by an oxygen-deficient structure and by nitrogen doping, Appl. Catal., 42 (2003) 403.

4. Zhao Z., Liu Q. Mechanism of higher photocatalytic activity of anatase $\mathrm{TiO}_{2}$ doped with nitrogen under visible-light irradiation from density functional theory calculation. J. Phys. D. Appl. Phys., 41 (2008) 1.

5. Sato $S$. Photocatalytic activity of $\mathrm{NO}_{\mathrm{x}}$-doped $\mathrm{TiO}_{2}$ in the visible light, Chem. Phys. Lett., 123 (1986) 126.

6. Beranek R., Neumann B., Sakthivel S. et al. Exploring the electronic structure of nitrogenmodified $\mathrm{TiO}_{2}$ photocatalysts through photocurrent and surface phototvoltage studies, Chem. Phys., 339 (2007) 11.

7. Cong Y., Zhang J., Chen F., Anpo M. Synthesis and characterization of nitrogendoped $\mathrm{TiO}_{2}$ nanophotocatalyst with high visible light activity. J. Phys. Chem. C, 111 (2007) 6976.

8. Kisch H., Sakthivel S., Janczarek M., Mitoraj $D$. A low-band gap, nitrogen-modified titania visible-light photocatalyst, J. Phys. Chem. C, 111 (2007) 11445.

9. Emeline A.V., Sheremetyeva N.V., Khomchenko N.V. et al. Photoinduced formation of defects and nitrogen-stabilization of color centers in $\mathrm{N}$-doped titanium dioxide, $\mathrm{J}$. Phys. Chem. C, 111 (2007) 11456.

10. Kuznetsov V.N., Serpone N. Photo-induced coloration and photobleaching of titanium dioxide in $\mathrm{TiO}_{2}$ /polymer compositions on UVand visible-light excitation into the color centers' absorption bands. Direct experimental evidence negating band gap narrowing in anion-/cation-doped $\mathrm{TiO}_{2}$, J. Phys. Chem. C, 111 (2007) 15277.

11. Nakano Y., Morikawa T., Ohwaki T., Taga Y. Band-gap narrowing of $\mathrm{TiO}_{2}$ films induced by N-doping, Phys., 376 (2006) 823.
12. Di Valentin C., Pacchioni G., Selloni A. et al. Characterization of paramagnetic species in $\mathrm{N}$ doped $\mathrm{TiO}_{2}$ powders by EPR spectroscopy and DFT calculations, J. Phys. Chem. B, 109 (2005) 11414.

13. Livraghi S., Paganini M.C., Giamello E.G. et al. Origin of photoactivity of nitrogen-doped titanium dioxide under visible light., J. Am. Chem. Soc., 128 (2006) 15666.

14. Batzill M., Morales E.H., Diebold U. Influence of nitrogen doping on the defect formation and surface properties of $\mathrm{TiO}_{2}$ rutile and anatase, Phys. Rev. Lett., 96 (2006) 026103.

15. Mitoraj D., Kisch H. On the mechanism of urea-induced titania modification, Chem. Eur. J., 16 (2010) 261.

16. Mitoraj D., Kisch H. The nature of nitrogenmodified titanium dioxide photocatalysts active in visible light., Angew. Chem. Int. Ed., 47 (2008) 9975.

17. Kisch H. Semiconductor photocatalysismechanistic and synthetic aspects., Angew. Chem. Int. Ed., 52 (2013) 812.

18. Gnatuk Yu., Smirnova N., Korduban O., Eremenko A. Effect of zirconium incorporation on the stabilization of $\mathrm{TiO}_{2}$ mesoporous structure, Surface and Interface Analysis, 42 (2010) 1276.

19. Linnik O., Petrik I., Smirnova N. et al. $\mathrm{TiO}_{2} / \mathrm{ZrO}_{2}$ thin films synthesized by PLD in low pressure $\mathrm{N}-, \mathrm{C}$ - and/or O-containing gases: structural, optical and photocatalytic properties, Digest Journal of Nanomaterials and Biostructures, 7 (2012) 1343.

20. Ptashko T., Smirnova N., Eremenko A. et al. Synthesis and photocatalytic properties of mesoporous $\mathrm{TiO}_{2} / \mathrm{ZnO}$ films with improved hydrophylisity, Adsorpt. Sci. Technol., 25 (2007) 35.

21. Zhang P., Shao C., Li X. et al. In situ assembly of well-dispersed $\mathrm{Au}$ nanoparticles on $\mathrm{TiO}_{2} / \mathrm{ZnO}$ nanofibers: A three-way synergistic heterostructure with enhanced photocatalytic activity, J. Hazard. Mater., 237 (2012) 331.

22. Gyoryova K., Balek V. Thermal stability of new $\mathrm{Zn}$ acetate-based complex compounds. J. Therm. Anal., 40 (1993) 519.

23. Smirnova N., Gnatyuk Yu., Eremenko A. et al. Photoelectrochemical characterization and photocatalytic properties of mesoporous $\mathrm{TiO}_{2} / \mathrm{ZrO}_{2}$ films, International Journal of Photoenergy, Article ID 85469 (2006) 1. 
24. Haiying $W$., Yanchun $H$. The photocatalytic property of nitrogen-doped $\mathrm{TiO}_{2}$ nanoball film, International Journal of Photoenergy, Article ID 179427 (2013) 6.

25. Peng W.Q., Yanagida M., Han L.Y. Rutileanatase $\mathrm{TiO}_{2}$ photoanodes for dye-sensitized solar cells, Journal of Nonlinear Optical Physics and Materials, 19 (2010) 673.

26. Nosaka Y., Matsushita M., Nishino J., Nosaka A.Y. Nitrogen-doped titanium dioxide photocatalysts for visible response prepared by using organic compounds, Sci. Technol. Adv. Mater., 6 (2005) 143.

27. Kobayakawa K., Murakami Y., Sato Y. Visiblelight active $\mathrm{N}$-doped $\mathrm{TiO}_{2}$ prepared by heating of titanium hydroxide and urea, J. Photochem. Photobiol. A., (2005) 170, 177.

28. Beranek R., Kisch H. Tuning the optical and photoelectrochemical properties of surfacemodified $\mathrm{TiO}_{2}$, Photochem. Photobiol. Sci., 7 (2008) 40.

29. Yuan J., Chen M., Shi J., Shangguan W. Preparation and photocatalytic hydrogen evolution of $\mathrm{N}$-doped $\mathrm{TiO}_{2}$ from urea and titanium tetrachloride, Int. J. Hydrogen Energy, 31 (2006) 1326.

30. Yin S., Ihara K., Aita Y. et al. Visible-light induced photocatalytic activity of $\mathrm{TiO}_{2-x} \mathrm{~A}_{y}(\mathrm{~A}=\mathrm{N}, \mathrm{S})$ prepared by precipitation route, J. Photochem. Photobiol. A., 179 (2006) 105.

31. Wang C.T., Wang, Lin J.C. Surface nature of nanoparticle zinc-titanium oxide aerogel catalysts, Appl. Surf. Sci., 254 (2008) 4500.

32. Linnik O., Smirnova N., Korduban O., Eremenko A. Gold nanoparticles in $\mathrm{Ti}_{1-\mathrm{x}} \mathrm{Zn}_{\mathrm{x}} \mathrm{O}_{2}$ films: synthesis, structure and application, Materials Chemistry and Physics, 142 (2013) 318.

33. Matsubara K., Danno M., Inoue M. et al. Characterization of nitrogen-doped $\mathrm{TiO}_{2}$ powder prepared by newly developed plasma- treatment system, Chemical Engineering Journal, 181 (2012) 754.

34. Zuoli H., Wenxiu Q., Yucheng H. et al. Electrochemical behavior and photocatalytic performance of nitrogen-doped $\mathrm{TiO}_{2}$ nanotubes arrays powders prepared by combining anodization with solvothermal process, Ceramics International, 39 (2013) 5545.

35. Alam M.J., Cameron D.C. Preparation and characterisation of $\mathrm{TiO}_{2}$ thin films by sol-gel method, J. Sol-Gel Sci. Technol., 25 (2002) 137.

36. Shu T., Xiang P., Zhou Z. et al. Mesoscopic nitrogen-doped $\mathrm{TiO}_{2}$ spheres for quantum dotsensitized solar cells, Electrochimica Acta., 68 (2012) 166.

37. Mai L., Huang C., Wanga D. et al. Effect of C doping on the structural and optical properties of sol-gel $\mathrm{TiO}_{2}$ thin films, Appl. Surf. Sci., 255 (2009) 9285.

38. Trautweina C., Kummererc K. Degradation of the tricyclic antipsychotic drug Chlorpromazine under environmental conditions, identification of its main aquatic biotic and abiotic transformation products by LC-MS(n) and their effects against environmental bacteria, J Chromatogr. B: Analyt. Technol. Biomed. Life Sci., 889-890 (2012) 24.

39. Smirnova N., Vorobets V., Linnik $O$. et al. Photoelectrochemical and photocatalytic properties of mesoporous $\mathrm{TiO}_{2}$ films modified with silver and gold nanoparticles, Sur. Interface Anal., 42 (2010) 1205.

40. Serpone $N$. Is the band gap of pristine $\mathrm{TiO}_{2}$ narrowed by anion- and cation-doping of titanium dioxide in second-generation photocatalysts, J. Phys. Chem. B, 110 (2006) 24287.

Received 25.07.2014, accepted 23.04.2015 